\title{
DIVERSIFICATION OF FARMING SYSTEMS IN POLAND IN THE YEARS 2006-2009
}

\author{
Anna KoŁodziejczaK, Tomasz KossowsKi \\ Adam Mickiewicz University, Institute of Socio-Economic Geography and Spatial Management, Poznań, \\ Poland \\ Manuscript received January 11, 2011, \\ Revised version January 28, 2011
}

\begin{abstract}
KoŁodziejczaK A., Kossowski T., Diversification of farming systems in Poland in the years 2006-2009. Quaestiones Geographicae 30(2), Bogucki Wydawnictwo Naukowe, Poznań 2011, pp. 49-56, 6 figs, 2 tables. DOI 10.2478/ v10117-011-0017-x, ISBN 978-83-62662-62-3, ISSN 0137-477X.
\end{abstract}

AвSTRACт: The use of methods based on the Gini coefficient and the Lorenz curve in studies of the spatial structure of agriculture offers a great possibility of presenting changes in it and assessing their causes. They provided a basis for a research on changes in the farming systems employed in Polish agriculture over the years 2006-2009. The results confirm there to be a further diversification of this sector of the economy, and even if slower than in the previous years, it shows agriculture to keep adapting to natural and economic conditions.

KEY WORDS: diversification, farming systems, Polish agriculture, Gini coefficient

Anna Kołodziejczak, Tomasz Kossowski, Institute of Socio-Economic Geography and Spatial Management, Adam Mickiewicz University, ul. Dzięgielowa 27,61-680 Poznań, Poland; e-mail: aniaka@amu.edu.pl, tkoss@amu.edu.pl

\section{Introduction}

The diversification of farming systems employed in Polish agriculture has recently become an object of interest to agricultural and regional policies. Diversification is one of the ways enhancing the development of regions through modernisation of agriculture, which creates possibilities of reducing unemployment and improving the comfort of living of the population in rural areas. The importance of diversification has been recognised in the priorities of the EU Common Agricultural Policy (CAP), which treats it as supportive of landscape protection, conservation and care, protection of areas with special environmental and cultural assets, protection against depopulation, preservation of tourist, recreational and hydrological functions, and of all other unconventional uses of the rural space. Measures for the diversification of farming systems are connected with the European Model of Agriculture and are intended to achieve both, economic (income-related) and extra-economic targets. At the regional scale, diversification can serve such purposes as preserving the cultural heritage, environmental and landscape protection, reducing rural unemployment, utilising the assets of regions and enhancing their attractiveness, and improving the population's standard of living. Diversification in agriculture agrees with the more general social targets that follow from the policy of multifunctional development of rural areas, but it also helps farmers to achieve their individual aims. From the point of view of an agricultural holding and a farmer himself, the following motives can be distinguished behind 
his decision: a rise in personal income, minimisation of production risk, better use of resources (of capital and labour), and development of the farm.

Definitions of diversification usually emphasise differences in the structure of production and show a high level of generality (Evans \& Ilbery 1993, Walford 2003, Meert et al. 2005). In practice, diversification in agriculture can assume several forms varying not only in terms of products and services offered, but also in the strength of relations between the basic functions (food production) and resources of an agricultural holding on the one hand and the natural environment on the other.

The aim of this article is to present the results of a research on spatial differences in the farming systems in Polish agriculture over the years 2006-2009 and to assess their diversification as expressed by the Gini coefficient.

\section{The notion of diversification}

Diversification refers to the place of work and production (an agricultural holding, village, region) and means an expansion of the range of products and services offered for sale. Its justification can be the need to use factors of production in a better way, or to lessen the risk of the production carried out. Diversification can be associated with pluri-activity, while multifunctionality can be said to be a result of this activity (Durand \& van Huylenbroeck 2003). In farming practice, diversification can assume a variety of forms differing not only in terms of products and services, but also in the strength of links with the basic functions and resources of an agricultural holding. The type of diversification based on land resources can involve horse breeding, growing of energy crops, or new forms of water management. Another definition sees diversification in a single farm engaging in various kinds of economic activity simultaneously, e.g. food production and tourism (Adamowicz 2004). Diversification can also involve other things besides a farm's production structure and income, e.g. modes of production, mostly the introduction of environment-friendly methods of farming in individual production activities or on the entire farm. In its most advanced form it involves a conversion into ecological production. The choice of a farming system springs from a variety of motives, including beliefs, market benefits, or legal requirements. It is a process relatively independent of the structure of production, since it still remains typically agricultural. What enforces diversification is an agricultural policy with its intervention instruments designed to introduce a variety of farming systems. Thus, the diversification of agriculture is understood as a variety of farming systems shaping the rural space and intended to adjust agriculture to environmental and economic conditions in the best possible way (Kołodziejczak 2010). It embraces the use of the resources of capital, labour and land for farming purposes, which leads to a spatial diversification of agriculture (Fig. 1).

In the model of the diversification of agriculture in terms of farming systems, conventional, sustainable and organic farming as well as farmland afforestation are distinguished. Conventional (industrialised) farming aims at a maximisation of production and profit by the agricultural producer. This model of agriculture involves the consumption of large amounts of industrial means of production (mineral fertilisers, pest control products, components for industrial animal feeds, labour-substituting machines).

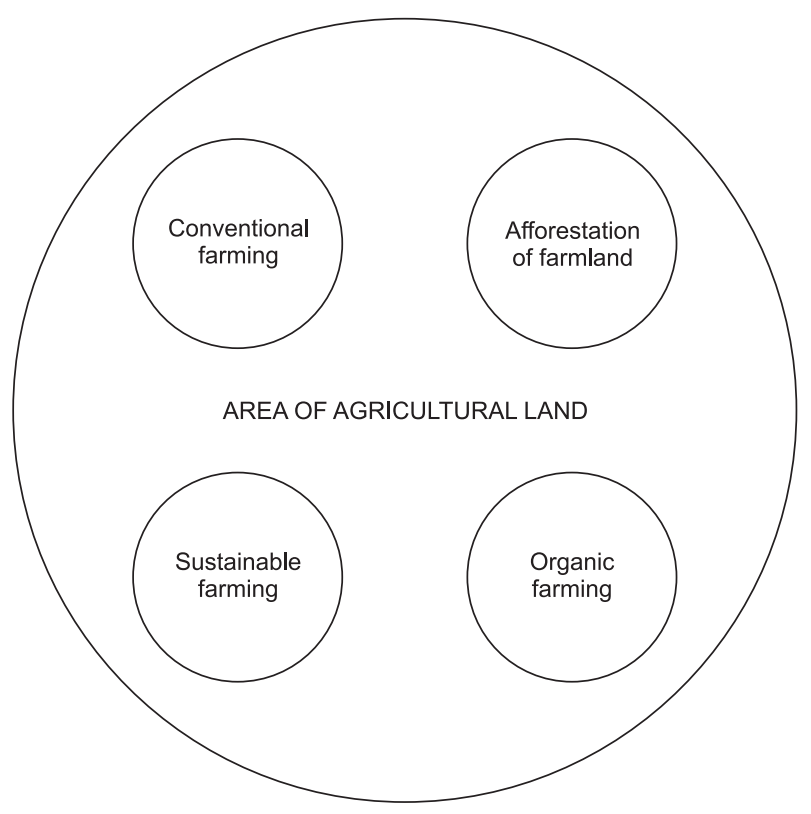

Fig. 1. Model of the diversification of agriculture in terms of farming systems. Source: own compilation. 
Sustainable farming is an organisation of agricultural production in such a way that it does not change the natural environment, or if there are changes, they are small and intended to eliminate environmental degradation, e.g. erosion. It involves the use of environment-friendly methods through the introduction of integrated plant protection and a nitrogen-balanced fertilisation plan.

Organic (ecological, biological) farming is a holistic system supporting biodiversity, the biological cycle, and the biological activity of the soil. In this model no artificial fertilisers or pesticides are used. It also recognises the fact that regional conditions call for local systems.

Farmland afforestation is one of the functions of multifunctional agriculture. Agriculture is multifunctional when it performs one or more functions apart from the production of food and raw materials for industry. The effect of afforestation on the development of multifunctional agriculture is both direct (by boosting the woodiness index, and hence creating conditions favourable to ecosystems and biodiversity), and indirect (by creating new job and income opportunities). The application of those agricultural models is one of the sources of diversification. If we take conventional farming as a basis (so far the most important model in Polish agriculture), diversification means a change in the farming system through the introduction of solutions offered by sustainable and organic farming as well as farmland afforestation.

\section{Measurement of diversification}

The measurement of diversification embraced poviats defined in the analysis as carriers of the variable under examination, while the total fund was the sum of the values of the variable in all its carriers in the sample. The analysis was carried out for Poland and its regions (voivodeships) on the basis of the area of agricultural land (AL) under the various farming systems. Its time range (2006-2009) was dictated by practical considerations, because the year 2006 marked the end of the first stage of programmes offering funds for various farming systems, while 2009 was the year of their continuation. The study focused on farm- land afforestation, organic farming, and sustainable farming, which together fall under three packages of the EU agri-environmental programme: Sustainable farming, Extensive management of meadows and pastures, and Protection of soil and water.

An assessment of diversification was made on the basis of an analysis of individual diversification indicators for each farming system. The index of farming system diversification (IFSD) was defined as a function of measures of inequality (MIE) in the distribution of a variable and the number of its carriers $(n)$ :

$$
I F S D=g(M I E, n)
$$

The distribution of a variable is uniform when all the carriers show the same value. With respect to diversification indices, they are a decreasing function of measures of inequality MIE and an increasing function of measures of equality $\mathrm{ME}$ (Davies 1980).

The diversification index was based on the Gini coefficient $(G)$, which is defined as double the area between the Lorenz curve and the 'full diversification' line. It is a measure of so-called pure diversification, which corresponds to the uniformity of a distribution. The Gini coefficient was calculated with the help of the following formula:

$$
G(y)=\frac{\sum_{i=1}^{n}(2 i-n-1) y_{i}}{n^{2} \bar{y}}
$$

where:

$y_{i}$ - the value of the $i$-th observation,

$\bar{y}$ - the mean value of all the observations, and

$n$ - the number of units.

The $y_{i}$ values are arranged in ascending order, and $i$ is the number of a unit in an increasing sequence. The Gini coefficient is a number in an interval of $[0 ; 1]$. If $G=0$, there is full uniformity of the distribution, with $G=1$, there is no such uniformity.

The values of the Gini coefficient determined from the sample and those estimated for the population differed only slightly, and the error of estimation was small. This confirmed that the sample was representative, because its structure for 
Table 1. Gini coefficients for Poland

\begin{tabular}{|c|c|c|c|c|}
\hline \multirow[b]{2}{*}{ Variable } & \multicolumn{2}{|c|}{2006} & \multicolumn{2}{|c|}{2009} \\
\hline & $\begin{array}{c}\text { Coefficient from } \\
\text { sample }\end{array}$ & $\begin{array}{l}\text { Coefficient estimat- } \\
\text { ed for population }\end{array}$ & $\begin{array}{c}\text { Coefficient from } \\
\text { sample }\end{array}$ & $\begin{array}{l}\text { Coefficient estimat- } \\
\text { ed for population }\end{array}$ \\
\hline \multicolumn{5}{|c|}{ Gini coefficient based on AL area } \\
\hline organic farming & 0.7061 & 0.7080 & 0.6930 & 0.6948 \\
\hline farmland afforestation & 0.6505 & 0.6522 & 0.6595 & 0.6612 \\
\hline sustainable farming & 0.6139 & 0.6156 & 0.5828 & 0.5843 \\
\hline
\end{tabular}

Source: own calculations.

all the variables studied was close to that of the population from which it was taken. The sample is big enough, hence one can assume, with a probability close to unity, that the distribution of a variable in the sample differs little from that in the general population (Table 1).

The values of the Gini coefficient determined for Poland on the basis of the AL area under the various farming systems in 2006 were 0.6139 0.7061 , as against $0.5828-0.6930$ in 2009 . These are mean values and they show the farming systems to be diversified only moderately. Both the Gini coefficients and the Lorenz curves for the years 2006 and 2009 show organic farming to be a bit more diversified than farmland afforestation and sustainable farming (Fig. 2). Over the study period the Gini figures for organic and sustainable farming dropped by 0.1 .

The values of the Gini coefficient for organic farming in 2006 ranged from 0.8056 in Wielkopolska to 0.3840 in Świętokrzyska Land. The diversification of organic farming was found to

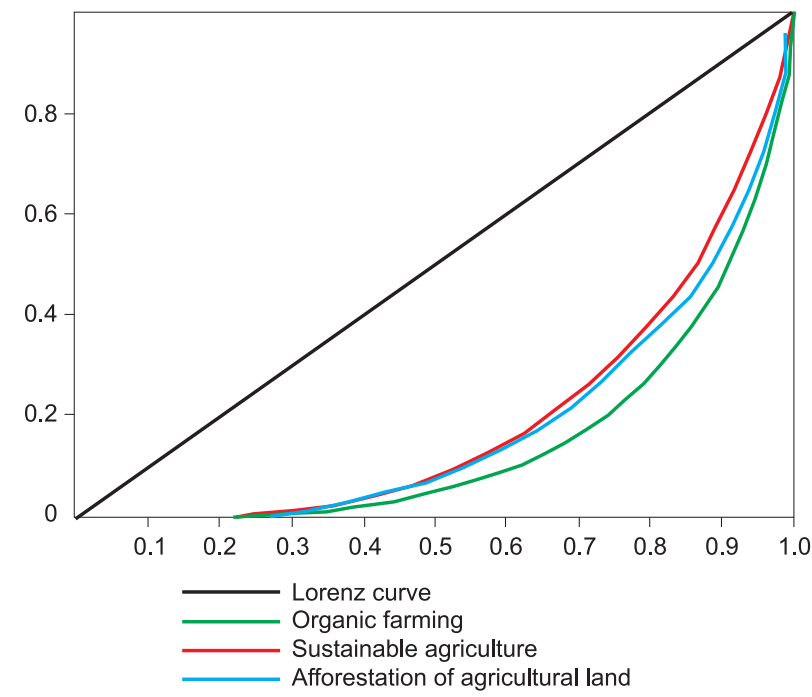

Fig. 2. Lorenz curves by farming systems in the years 2006 and 2009.

Source: own compilation. be high not only in Wielkopolska, but also in voivodeships forming a belt extending from Silesia, Małopolska and Subcarpathia in the south, through Lublin and Mazovia, to Łódź in central Poland (Fig. 3). The diversification of organic farming was moderate in Lower Silesia, KujaviaPomerania, and West Pomerania. In 2006 only five voivodeships: Lower Silesia, Podlasie, Silesia, Kujavia-Pomerania and Pomerania, registered an increase in the values of the Gini coefficient based on the AL area under this farming system. A reverse tendency, i.e. an increase in the uniformity of the farming system, could be observed largely in the voivodeships of north-western and central Poland extending in a compact belt from West Pomerania through Lubuska Land, Wielkopolska, Łódź and Mazovia to Warmia-Mazuria in the north, and in the voivodeships of southeastern Poland, viz. Małopolska, Świętokrzyska Land and Subcarpathia. In terms of an increase in the concentration of organic farming, Opole was clearly the leader. The factor differentiating the spatial distribution of this farming system was the distribution of protected areas and permanent grassland.

In 2006 the diversification of AL area under afforestation was high in Silesia (0.8006) and low in Lubuska Land (0.4245), Świętokrzyska Land (0.4432), Kujavia-Pomerania (0.4732), and Pomerania (0.4886). It was moderate in the voivodeships of central and north-eastern Poland (Fig. 4). In 2009 the biggest drop in the values of the Gini coefficient (of more than 0.01) was found in Subcarpathia, Pomerania and Lower Silesia, which means that there was a tendency to concentrate land intended for afforestation. The reason behind this development is that AL afforestation involves a long-term elimination of land from agricultural use. The process of diversification of farmland afforestation was observed to be es- 

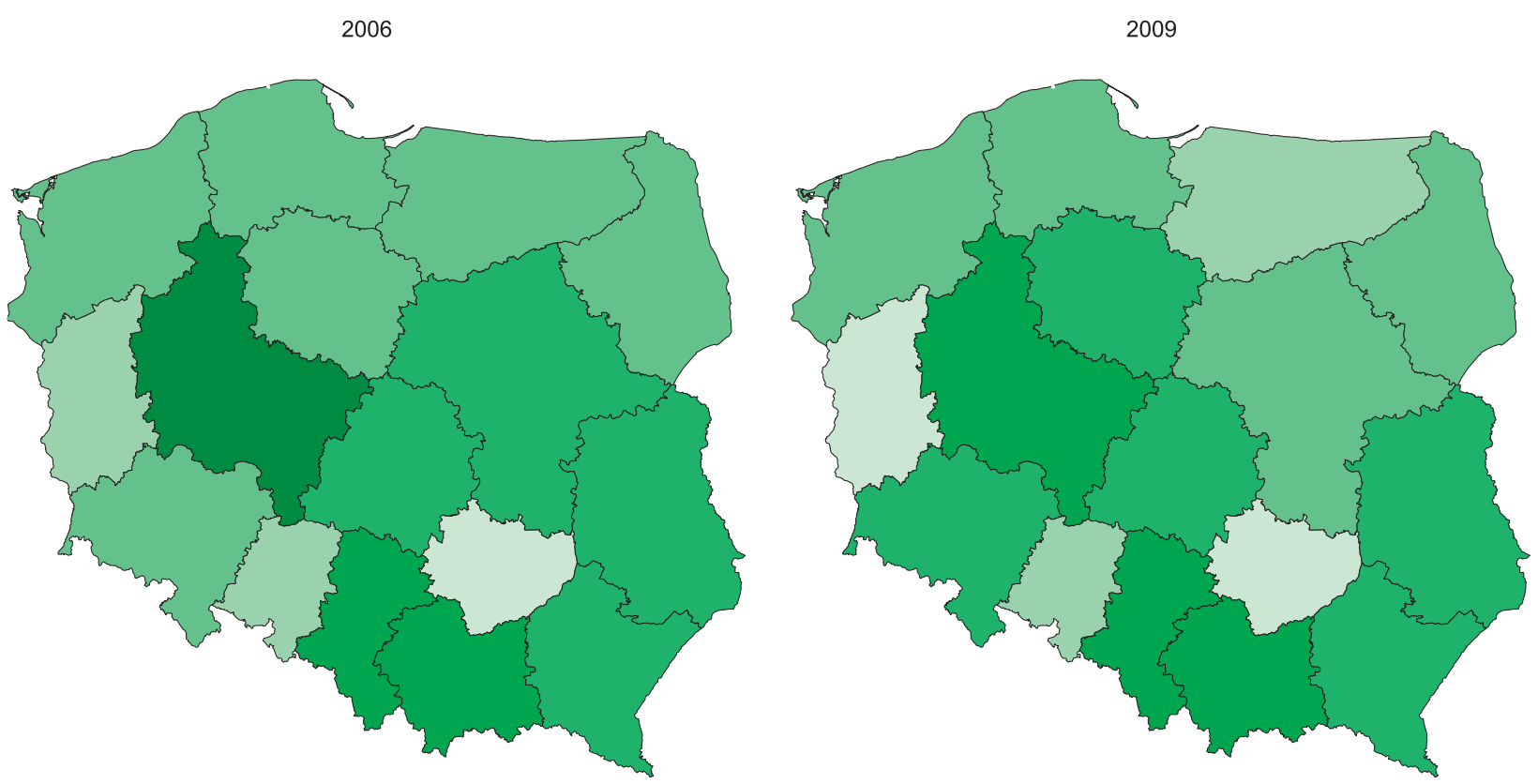

Gini coefficient:

$\begin{array}{lllllll}0.30 & 0.40 & 0.50 & 0.60 & 0.70 & 0.80 & 0.90\end{array}$

Fig. 3. Organic farming by AL-based Gini coefficient in Poland in the years 2006 and 2009. Source: own compilation.

pecially intensive in north-eastern Poland, i.e. in Lublin, Mazovia and Podlasie voivodeships.

In 2006 sustainable farming was found to be highly diversified in the voivodeships of south-eastern Poland, i.e. Subcarpathia (0.6898), Małopolska (0.6425) and Silesia (0.7695). It was poorly diversified in western Poland (Fig. 5). In 2009 the intensification of diversification of AL under sustainable farming was noted in Podlasie, Mazovia, Łódź, Lubuska Land and West Pomerania. A marked increase in the concentration of sustainable farming was again shown by Opole voivodeship.

The rate and scale of transformation in agriculture lead to changes in the diversity of farming systems. Those changes are reflected in a synthetic way by the index of farming system diversification calculated for the three systems involved. The index assumes values from 0 (minimum diversity - the whole of agricultural land is under a single farming system) to 1 (maximum diversity - each system embraces the same area of farmland).

The 4-year study period displayed a moderate rate of diversification, and hence only a faint tendency to develop multifunctionality in agri- culture. This shows in a rather low dynamics of increase in the diversity of the farming systems (Table 2). Among the factors of this process the

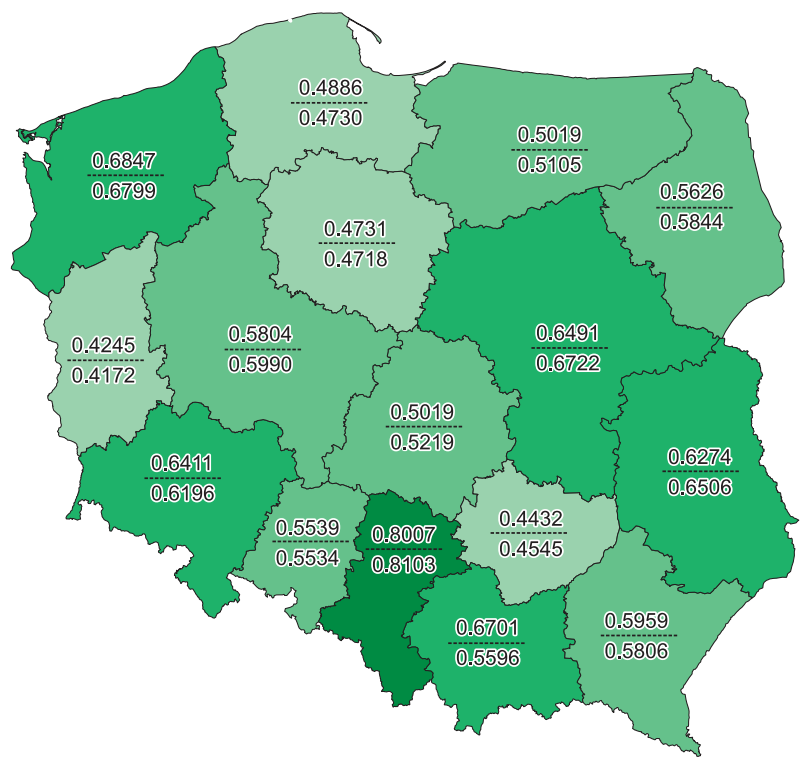

Gini coefficient:

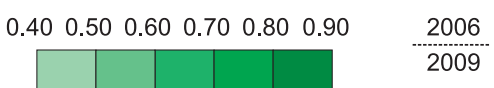

Fig. 4. Afforestation by AL-based Gini coefficient in Poland in the years 2006 and 2009.

Source: own compilation. 

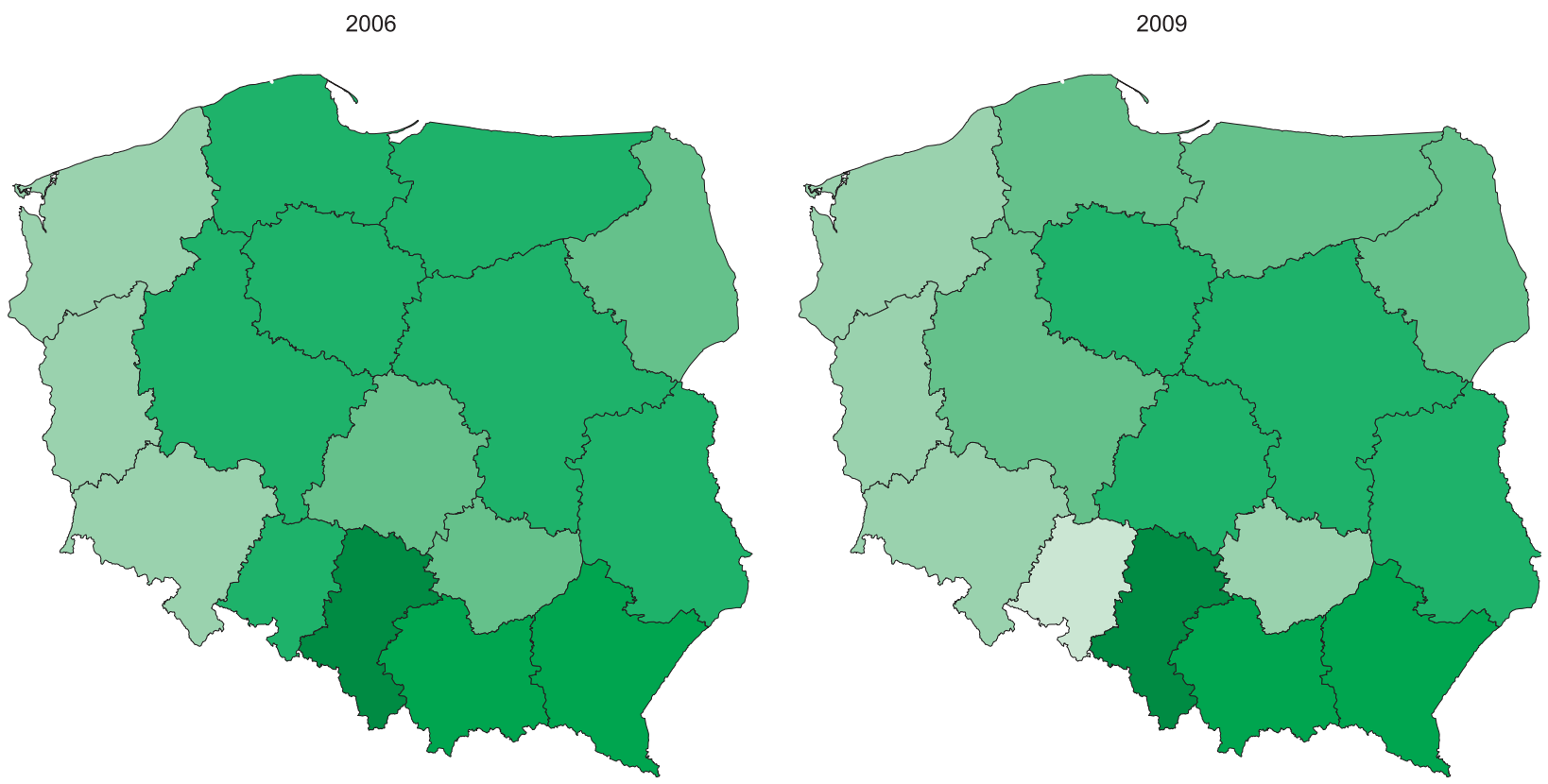

Gini coefficient:

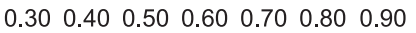

Fig. 5. Sustainable agriculture by AL-based Gini coefficient in Poland in the years 2006 and 2009. Source: own compilation.

one that has to be mentioned in the first place is the EU Common Agricultural Policy, whose financial instruments have an impact on agricultural activity. Between 2006 and 2009, the process of diversification of agriculture intensified in Silesia, Małopolska, Subcarpathia and Wielkopol-

Table 2. Synthetic indices of farming system diversification for voivodeships in the years 2006 and 2009.

\begin{tabular}{|l|c|c|r|}
\hline \multirow{2}{*}{\multicolumn{1}{c|}{ Voivodeship }} & \multicolumn{2}{|c|}{ Diversification index } & \multirow{2}{*}{$\begin{array}{c}\text { Index } \\
\text { changes }\end{array}$} \\
\cline { 2 - 3 } & $\mathbf{2 0 0 6}$ & $\mathbf{2 0 0 9}$ & 0.0030 \\
Lower Silesia & 0.5423 & 0.5453 & 0.0067 \\
Kujavia-Pomerania & 0.5442 & 0.5375 & -0.006 \\
Lublin & 0.5864 & 0.5896 & 0.0031 \\
Lubuska Land & 0.3745 & 0.3751 & 0.0007 \\
Eódź & 0.5154 & 0.5639 & 0.0485 \\
Małopolska & 0.6781 & 0.6681 & -0.0100 \\
Mazovia & 0.5899 & 0.5861 & -0.0038 \\
Opole & 0.5339 & 0.4105 & -0.1234 \\
Subcarpathia & 0.6603 & 0.6449 & -0.0154 \\
Podlasie & 0.5075 & 0.5297 & 0.0222 \\
Pomerania & 0.5137 & 0.4898 & -0.0239 \\
Silesia & 0.7764 & 0.7805 & 0.0021 \\
Świętokrzyska Land & 0.4119 & 0.4068 & -0.0050 \\
Warmia-Mazuria & 0.5073 & 0.4991 & -0.0081 \\
Wielkopolska & 0.6389 & 0.6088 & -0.0301 \\
West Pomerania & 0.5245 & 0.5164 & -0.0081 \\
\hline Poland & 0.6568 & 0.6451 & -0.0117 \\
\hline
\end{tabular}

Source: own calculations. ska. In Wielkopolska it was caused by an increase in the AL area under organic farming.

A tendency towards a concentration of a single farming system was noted in Lubuska Land, Świętokrzyska Land and Opole: in Lubuska Land and Opole there was an increase in the AL area occupied by sustainable farming, and in Świętokrzyska Land, by organic farming (Fig. 6). During the four years of study, an increase in the index of farming system diversification was recorded in six voivodeships: Lower Silesia, Lublin, Lubuska Land, Łódź, Podlasie and Silesia.

The introduction of the various farming systems brings about a significant re-evaluation of the agricultural function in rural areas. In the opinion of Zegar (2008), it throws a different light on the question of progress in agriculture, which can no longer be associated one-sidedly with concentration, specialisation and intensification understood in a conventional way. Today progress does not mean an increase in power but in knowledge, since we are now much more aware of the possibilities and threats involved in ignoring natural conditions, and especially of the drawbacks of industrialised farming. It also turns out that it is possible to overcome environmental 


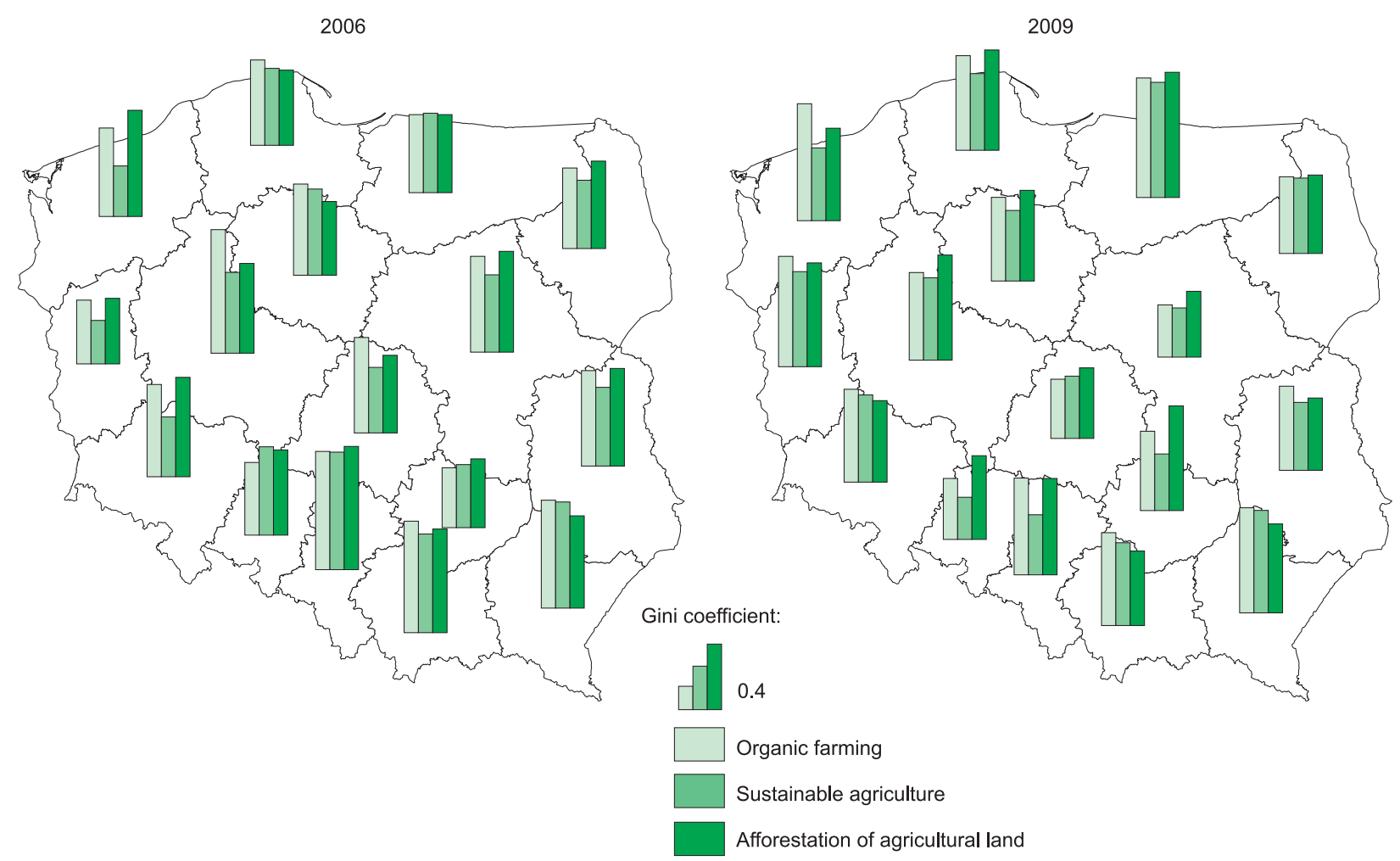

Fig. 6. Farming systems by AL-based Gini coefficient in Poland in the years 2006 and 2009. Source: own compilation.

limitations by employing suitable farming systems, and this leads to the development of multifunctionality in agriculture.

\section{Summing up}

The adjustment of Gini coefficients to a spatial analysis of farming systems by introducing a synthetic index has offered a new perspective on this research issue. The 2006 and 2009 Gini figures show organic farming to be a bit more diversified than farmland afforestation and sustainable farming. What primarily determined the diversification of the farming systems was the intensity of agricultural production organisation and the intensity of farming. In the group of regions with an accelerated rate of diversification in terms of AL area were the voivodeships of Silesia, Małopolska, Subcarpathia and Wielkopolska. This suggests that the agrarian structure does not play a decisive role there. In the case of Silesia, the diversifying factors were its dense settlement network (the metropolitan area) and the concentration of farms in mountainous areas. In the group of regions with a slow rate of diversifi- cation of the farming systems were the voivodeships of Lubuska Land, Opole and Świętokrzyska Land. In Lubuska Land and Opole, there was an advancing increase in the AL area occupied by one system, namely sustainable farming. In Świętokrzyska Land, there was an increase in the concentration of organic farming, and the factors that decided about the choice of this system were extensive areas of protected land and a big number of small farms.

The research has confirmed that through the diversification of the farming systems under the influence of economic factors brought about by the EU Common Agricultural Policy, Polish agriculture keeps adjusting to the natural conditions ever better.

\section{References}

AdAmowicz M., 2004. Wielofunkcyjne gospodarstwo rolne jako podmiot $\mathrm{w}$ rozwoju wsi i rolnictwa (A multifunctional agricultural holding as an agent in the development of rural areas and farming). In: Adamowicz M. (ed.), Wiejskie gospodarstwa domowe w obliczu problemów transformacji, integracji $i$ globalizacji. Prace Naukowe KPAiM nr 33, SGGW, Warszawa: 25-42. 
DAVIES S., 1980. Measuring industrial concentration: An alternative approach. Review of Economics and Statistics 62 (2): 306-309.

Durand G. \& van Huylenbroeck G., 2003. Multifunctionality and rural development: a general framework. In: Huylenbroeck G. \& Durand G. (eds), Multifunctional agriculture. A new paradigm for European agriculture and rural development. Ashgate, Aldershot: 1-16.

Evans N. \& Ilbery B., 1993. The pluriactivity, part-time farming and farm diversification debate. Environment and Planning A 25: 945-959.

KoŁodziejczAK A., 2010. Modele rolnictwa a zróżnicowanie przestrzenne sposobów gospodarowania w rolnictwie polskim (Models of agriculture and the spatial diversification of farming systems in Poland). Wydawnictwo Naukowe UAM, Poznań.

Meert H., van Huylenbroeck G., Vernimmen T., Bourgeois M. \& van Hecke E., 2005. Farm household survival strategies and diversification on marginal farms. Journal of Rural Studies 21: 81-97.

WALFORD N., 2003. A past and future for diversification on farms? Some evidence from large-scale commercial farms in south-east England. Geografiska Annaler B 85: 51-62.

ZEGAR J., 2008. Konkurencyjność rolnictwa w dobie globalizacji (Competitiveness of agriculture in the times of globalisation). Roczniki Naukowe, SERiA X (1): 503-514. 